\title{
MAKROEKONOMIE V PRAXI
}

\section{František Táborskýa,b}

Lelie Lipschitz, Susan Schadler: Macroeconomics for Professionals:

A Guide for Analysts and Those Who Need to Understand Them

Milton Keynes, Velká Británie: Cambridge University Press, 2020. 2. vydání. 290 stran. ISBN 978-1-316-51589-1

Kniha Makroekonomie pro profesionály dvou ekonomů z Mezinárodního měnového fondu (MMF) navazuje na její první vydání z roku 2019. Oba autoři mají bohatou zkušenost z nadnárodních institucí, akademické i privátní sféry finančního světa, kterou se snaží spojit s tradičním výkladem makroekonomické teorie. Výsledkem tak je podle samotných autorů komplexní „manuál“, umožňující posouzení makroekonomické politiky vlády a centrální banky, jejich dopadů včetně dlouhodobého výhledu na 250 stranách čistého obsahu. Ačkoli kniha působí na první pohled jako klasická učebnice makroekonomie, jejím primárními čtenáři by měli být profesionálové, kteří hledají ucelený přehled současných makroekonomických teorií, doplněných o aktuální kontext ekonomického a finančního dění. Kniha tak jednoznačně není určena „začátečníkům“, tedy studentům bakalářského stupně nebo studentům mimo národohospodářské obory, nebot' $\mathrm{k}$ její četbě je již nutné mít předchozí zkušenost s problematikou. Řadě kapitol chybí hlubší teoretické vysvětlení problémů, na druhé straně čtenář ocení praktické ukázky z reálného světa, resp. využití daných teorií v praxi. Celou knihu provází nespočet boxů, tabulek a grafů s aktuálními př́iklady a daty. To je pravděpodobně její největší benefit oproti „klasickým“ učebnicím makroekonomie, které často selhávají v představení teorie v praxi, což je z mého pohledu hlavním účelem studia. Autoři si stanovují řadu cílů, kterých by čtenář měl pomocí této knihy dosáhnout. Na prvním místě uvádí „čtení dat“, které umožňuje kritické vyhodnocení vývoje reálného světa a politiky. Z jejich pohledu je především nutné porozumět základním ekonomickým záznamům, jako jsou národní účty, účetní bilance vlády, centrální banky, bankovního sektoru nebo mezinárodního obchodu či platební bilance a zahraniční pozice

\footnotetext{
a Komerční banka, Praha

b Vysoká škola ekonomická v Praze, Fakulta financí a účetnictví, Praha

E-mail: frantisektaborsky@gmail.com
} 
země. Každý z těchto systémů má vlastní konvence a standardy, jejichž znalost je klíčová k vyhodnocení aktuálního stavu a dalšího vývoje. Na druhé místo staví pochopení makroekonomických vztahů mezi jednotlivými proměnnými a obecně používaného jazyka ekonomů, identit, modelů a prognóz. Dále by čtenář měl být schopen vyhodnotit dopady rozhodnutí a opatření hospodářských politik, identifikovat slabiny ekonomiky a spouštěče potenciálních krizí.

Kniha je rozdělena do šesti kapitol mimo úvod, které odpovídají tradiční struktuře klasických učebnic makroekonomie a obdobně jsou i zakončeny sadou otázek k zamyšlení či procvičení představené teorie. Nevýhodu zde vidím v absenci správných odpovědí. Ty však jsou k nalezení v online podobě na internetových stránkách autorů včetně dalších pomůcek k výuce i samostudiu.

První kapitola se věnuje měření a analýze agregátních ukazatelů ekonomiky, resp. jejího výstupu z pohledu nabídkové a poptávkové strany a neopomíjí ani teorii hospodářských cyklů. Definuje faktory ovlivňující aktuální a potenciální produkt, jejich propojení $\mathrm{s}$ analýzou hospodářské politiky. Autoři kladou důraz na systém národních účtů a jejich využití pro identifikování nabídkových šoků a tvorbu hospodářské politiky. Kromě definic základních pojmů nutných pro pochopení dalších kapitol knihy se zde můžeme potkat s prvními boxy, které z praktického hlediska představují např. různé metody měření HDP, variantní metody odhadu potenciálního produktu (včetně př́stupu MMF), a to na př́kladu několika vyspělých ekonomik s odkazy na aktuální reporty zmíněné instituce.

Druhá kapitola je věnovaná inflaci, relativním cenám a očekáváním ekonomických agentů. V první části jsou diskutovány různé metody měření agregátní cenové hladiny, její změny a role měnové politiky. Druhá část rozebírá ceny a jejich vývoj v makroekonomickém kontextu a analýze, tzn. cenu jednotky práce a deflátor přidané hodnoty, obchodovatelné a neobchodovatelné části indexu spotřebitelských cen, jejich faktory a různé metody měření mezinárodní konkurenceschopnosti. Třetí část se věnuje reálným a nominálním úrokovým sazbám, inflačním očekáváním, úrokovým arbitrážím a mezinárodnímu propojení. Text opět doprovází řada boxů a grafů, které zasazují představenou teorii do praxe, např. ukázkou vývoje deflátoru HDP a inflace v Izraeli a jejich spojením se směnnými relacemi nebo ukázkou Balassova-Samuelsonova efektu v př́ípadě Slovenska.

Třetí kapitola pokrývá měnovou politiku, její problémy, proticykličnost a její limity. Navíc je pozornost věnována i bilanci centrálních bank a celého bankovního sektoru. Kapitola tradičně začíná historií a vývojem měnové politiky od brettonwoodského měnového systému, pres cílování měnových zásob až po současné cílování inflace. Praktické boxy pak dokreslují měnovou politiku v praxi na aktuálních tématech, jako byla cesta Bulharska k zavedení režimu měnového výboru, Mundellův-Flemingův model domácí a zahraniční rovnováhy nebo představení konceptu Friedmanových 
„helicopter money“, které se v poslední době stále častěji vrací do diskusí o nových možnostech měnové politiky.

Čtvrtá kapitola se věnuje fiskální politice, vlivu vlády na makroekonomický vývoj skrze daňovou politiku a její výdaje. Celá kapitola je rozdělena do čtyř částí: 1) národní účty a další vládní výkazy včetně jejich stavů a toků, 2) analýza a vyhodnocení kredibility fiskální politiky a rozpočtových výhledů, 3) proticyklická fiskální politika a její realizace, porozumění automatickým fiskálním stabilizátorům a diskrečním opatřením vlády a 4) udržitelnost veřejných rozpočtů z pohledu dluhové dynamiky při různých scénářích ekonomiky. Opět je teorie doplněna o několik dobře zpracovaných boxů z praxe, např. srovnání mezery výstupu a strukturálního deficitu veřejných financí v př́padě Velké Británie, které opět vycházejí z dat MMF, nebo problematiky fiskálních multiplikátorů na př́ikladu Řecka v době poslední hospodářské krize.

Pátá kapitola se zabývá moderním a bezpochyby aktuálním tématem finanční stability. Pokrývá potenciální hloubku (včetně možné prevence) makroekonomické nestability vycházející z finančního sektoru. Hlavní pozornost se upíná na obchodní banky, které jsou považovány za jádro finančního světa. První část popisuje princip finanční páky a její vliv na procykličnost, historii regulace a dohledu, nafukování cenových bublin a cestu do krize. Dále se kapitola věnuje bilancím komerčních bank, kapitálové přiměřenosti, nestabilním zdrojům financování a nedostatku likvidity. Přes tyto koncepty se dostává ke snaze zlepšit mikro- a makroobezřetnostní politiku a zajistit finanční stabilitu. Zvláštní pozornost je věnována finančním krizím v rozvíjejících se ekonomikách a jejich zkušenostem s řešením pomocí různých politik. Paradoxně ale tato kapitola obsahuje nejméně př́íladů z praxe, ačkoli se jich jen z posledních let nabízí hned několik. Útěchou může být alespoň bohatá sada grafů a dat bankovního sektoru pro znázornění vývoje a aktuálního stavu zaváděné regulace.

Poslední kapitola se tradičně věnuje vnějšímu prostř̌edí ekonomiky, mezinárodním vztahům a jejich analýze. V podstatě dává dohromady všechny předchozí kapitoly a zasazuje je do mezinárodního kontextu. Popisuje vliv domácí ekonomiky, měnové a fiskální politiky a finančního sektoru na zahraničí a naopak. První část představuje koncept platební bilance a její jednotlivé složky. Dále se posouvá k čisté investiční pozici země jakožto stavové alternativě platební bilance. Následuje definice cílů analýzy obou zmíněných výkazů: 1) domácí růst ekonomiky, 2) domácí stabilita a využití zahraničních úspor, 3) konkurenceschopnost, 4) globální dysbalance (primárně přebytky a deficity běžných účtů) a 5) zranitelnost vưči externím finančním krizím. Vzhledem k pracovní a vědecké historii obou autorů je pochopitelné, že toto téma je, oproti předchozí kapitole, nejbohatší na ukázky z praxe. Na př́íladu Chile a Peru je prezentována zranitelnost ekonomiky díky vysoké závislosti na exportu jednoho produktu (mědi). Samostatný box je věnován 
metodice MMF pro vyhodnocení vnějších vztahů ekonomiky a jejím výhodám a slabinám. V této souvislosti stojí za pozornost i box o mezinárodních nákazách v př́ípadě finanční krize a zásazích nadnárodních institucí v čele s MMF.

Jak autoři sami uvádějí v úvodu, kniha není akademickou učebnicí, ale návodem, resp. průvodcem světem makroekonomie, který klade důraz na pochopení zpráv, reportů, výkazů, dat a dalších prvků z ekonomického světa. To autoři splnili beze zbytku. Jindy rozsáhlé definice a matematická odvození teorií jsou nahrazeny stručným popisem problému a ukázkou z reálného světa, doplněné o aktuální data a pohled MMF. To je bezesporu největší devizou této knihy ve srovnání s tradičními učebnicemi makroekonomie. Zároveň je text napsán srozumitelným jazykem a čtenáře neodradí ani svou délkou. Oceňuji tak moderní př́stup autorů a snahu pojmout až ,standardizovanéc téma novým způsobem s cílem dosáhnout na neobsazenou část čtenářù. 